\title{
LOADING, UNLOADING AND SHEARING TESTS CARRIED OUT IN UNDERGROUND WORKS INCLUDING STRESS MEASUREMENTS
}

\author{
ESSAIS DE CHARGEMENT, DE DECHARGEMENT ET DE CISAILLEMENT EN TRAVAUX \\ SOUTERRAINS Y COMPRIS LES MESURES DES CONTRAINTES
}

\section{SHARP John C.,**}

\section{Introduction}

The title of this topic includes a number of important elements that can be classed as follows:

- The in situ nature of the tests implies that they are essentially direct measurements of rock mass response**. - The scale and number of the tests must be directly related to the nature of the rock mass such that a representative sample is involved.

- The loading characteristics including both force and stiffness considerations must be directly related to the proposed engineering structure.

- The essence of the tests is to provide direct observations of rock response that can be used as design parameters.

The type of tests that are commonly employed include the following:

- Load-displacement measurements to determine rock mass deformability,

- shear-displacement measurements to determine rock mass shear strength,

- stress measurements to determine the initial state of stress in the rock,

- thermal hea ting tests to determine the thermomechanical response of the rock.

In addition to individual parameter assessment, tests are often carried out on prototype structures such as underground operings and pressure tunnels where rock mass conditions in relation to the applied loadings might be critical or where complex interactive loading mechanisms are involved.

For the planning and assessment of in situ testing programmes, three criteria need to be carefully considered as follows:

- Test scale.

- Stress state of the test sample.

- Stiffness or confinement of the test sample.

Before proceeding into specific test areas, it is perhaps useful to reflect on the value of the testing process in relation to the final design product. Throughout the development of soil and rock mechanics there have been two poles of thought on testing as follows:

* Consultant in Rock Engineering, San Peter, Jersey, Channel Islands (U.K.)

** The term rock mass is used in this report to emphasise the assemblage of discrete material pieces. Many of the remarks are equally applicable to soils.
- undertake a large number of relatively quick, cheap tests to provide an overall coverage of the site - perform THE UNIQUE large scale in situ test.

Those that live exclusively at the poles do so at their peril. Those that combine both approaches usually find success.

In planning in situ test programmes it is therefore essential to have a hierarchy of tests that provide a complete spectrum of answers to cover all aspects of the design process. It is well known that large scale in situ tests provide extremely valuable DIRECT observations of rock mass behaviour whilst other smaller scale tests (typically performed in boreholes) and geophysical tests generally provide INDIRECT values that must be calibrated by overall CONTROL measurements from the DIRECT observations.

In the evolution of rock mechanics great pains were taken to try and relate laboratory values to in situ properties. In rock masses that not only contain material but also gaps (joints) with different or no material, relationships could often not be found. Laboratories were than deserted and people left for the field. Unfortunately it is my belief that in many cases people took their laboratory training into the field and continued in their former ways by trying to execute small scale borehole tests and again relate this to the rock mass in an attempt to produce design properties. In some ways they were simply testing outwards from their core sample instead of inwards.

Whilst all this activity was proceeding a group of people called Engineers (who were somewhat sceptical about the borehole people and their gadgets or 'patentes') continued to build projects including dams on difficult foundations and large underground structures. Fortunately for us today measurements were made on the overall response of the rock mass in relation to the construction activity that have provided us with an empirical basis for design.

It is from this empirical understanding of rock mass behaviour that rock mass test programmes should be planned. Every site has its specific features and every engineering structure imposes different loading conditions. Thus testing will always be required if meaningful rock mass properties for design are to be obtained. The scope of the testing will be dictated by both the rock mass conditions at the site and an estimate of the likely effects of the rock behaviour on the final engineering product. At this point it is worth mentioning that we are experiencing an ever increasing participation of the rock in the final engineering product and this can be well demonstrated for underground structures in the field of rock reinforced cavern arches (as a replacement for thick concrete arches) and in pressure tunnels 

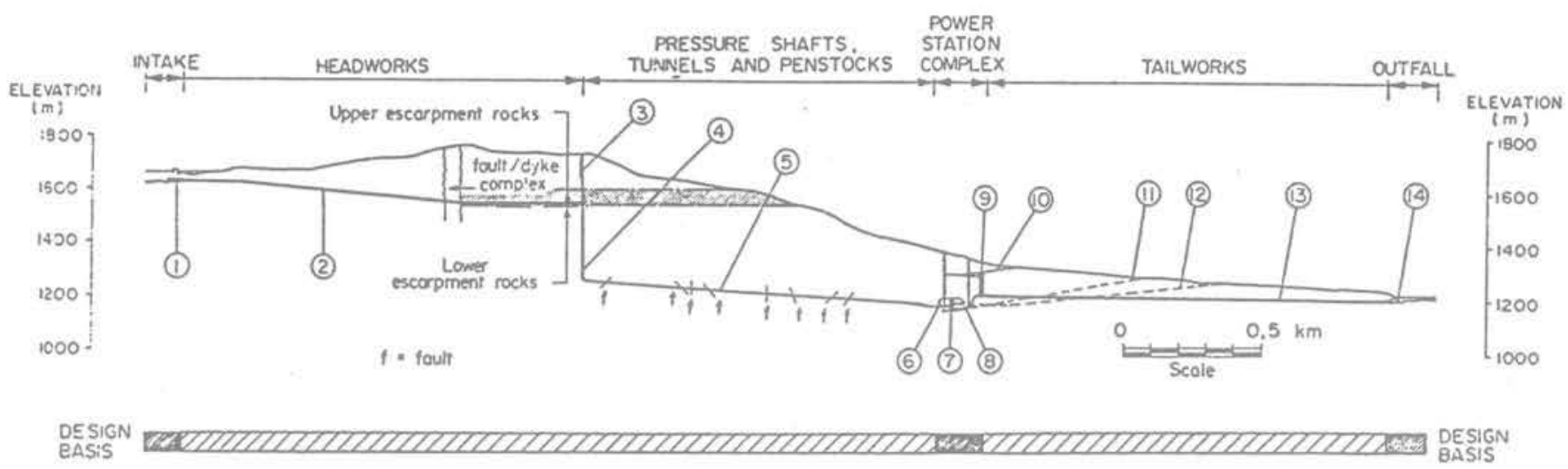

OVERALL ALIGNMENT

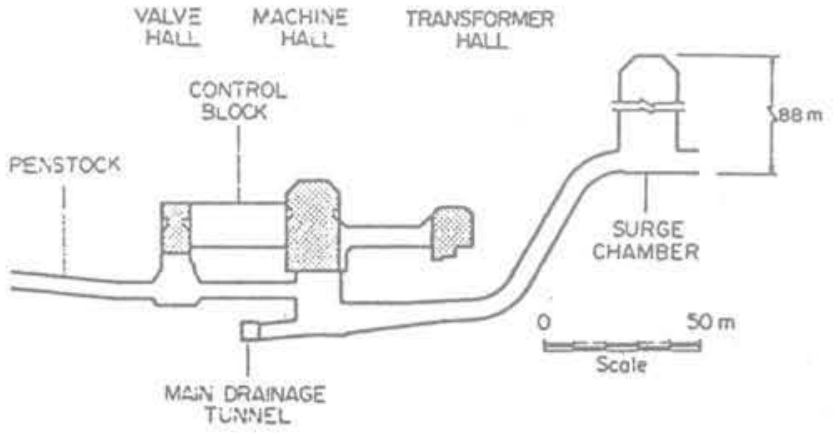

POWER STATION COMPLEX

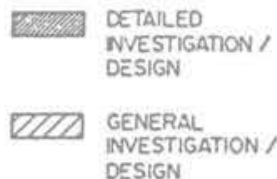
DESIGN
(1) HEADRACE INTAKE

(2) TWIN HEADRACE TUNNELS

(3) TWIN SURGE SHAFTS

(4) TWIN PRESSURE SHAFTS

(5) TWIN PRESSURE TUNNELS/ PENSTOCKS

(6) VALVE HALL

(7) MACHINE HALL

(B) TRANSFORMER HALL

(9) TWIN SURGE CHAMBERS

(0) AUXILARY ACCESS TUNNEC.

(11) EXPLORATORY ADIT

(12) MAIN ACCESS TUNNEL

(13) SINGLE TAILRACE TUNNEL

(44) TAILRACE TUNNEL PORTAL

Fig. 1: Drakensberg pumped storage scheme - Longitudinal section

where reliance on the rock for long term support purposes has reduced the need for expensive, thick steel linings. A fairly comprehensive example of underground testing can be found at the Drakensberg Project (Mellors and Sharp 1982) the overall layout for which is shown on Figure 1 and the exploratory works on Figure 2.

The scheme proposals involved two major features for which little precedence was available as follows:

- Excavation and permanent stabilisation of an underground power station complex in relatively weak argillaceous rocks that were subject to deterioration on exposure.

- Use of concrete-lined pressure tunnels in the relatively deformable argillaceous rocks with heads in excess of $500 \mathrm{~m}$. (Sharp \& Gonano 1982).

Because of the nature of the potential engineering problems, an overall testing strategy that included the following elements was developed:

- Full scale prototype structures.

- Large scale in situ design tests at selected sample locations.

- Small scale in situ classification tests over a widespread area.

- Stress measurements at critical locations over the project alignment.

A breakdown of the principal tests in relation to the main scheme elements is given in Table 1.

In reviewing the papers submitted to the Symposium an attempt has been made to evaluate the purpose and scope of the test measurements and their justification or otherwise in relation to our current understanding of rock mass behaviour as well as the engineering structure being investigated. The tests in Topic 6 should fall into the following categories and the papers have been grouped accordingly:

I In situ Design Property Tests

- Rock Mass Deformability

- Shear Strength

- Thermal Properties

II In Situ Stress Measurements

III Full Scale In Situ Observations

The distribution of papers received in relation to the above groups is indicated on Table 2. It is particularly encouraging to see a significant number of papers dealing with full scale observations. Most of the papers dealt either with dam foundations or pressure tunnel design and have been grouped accordingly.

Tests at a smaller scale in boreholes which can usually only be used indirectly to determine rock mass property values have already been addressed in Topics 1 and 5. The associated and important range of geophysical tests has been covered in Topic 2.

In terms of test methods, the International Society for Rock Mechanics has published a number of standards covering most test types and therefore the subject of basic test methodology will not be addressed here.

\section{In Situ design property tests}

Overall, twelve contributions were received all of which were addressed wholly or in part to the measurement of 
ELEVATION (m)
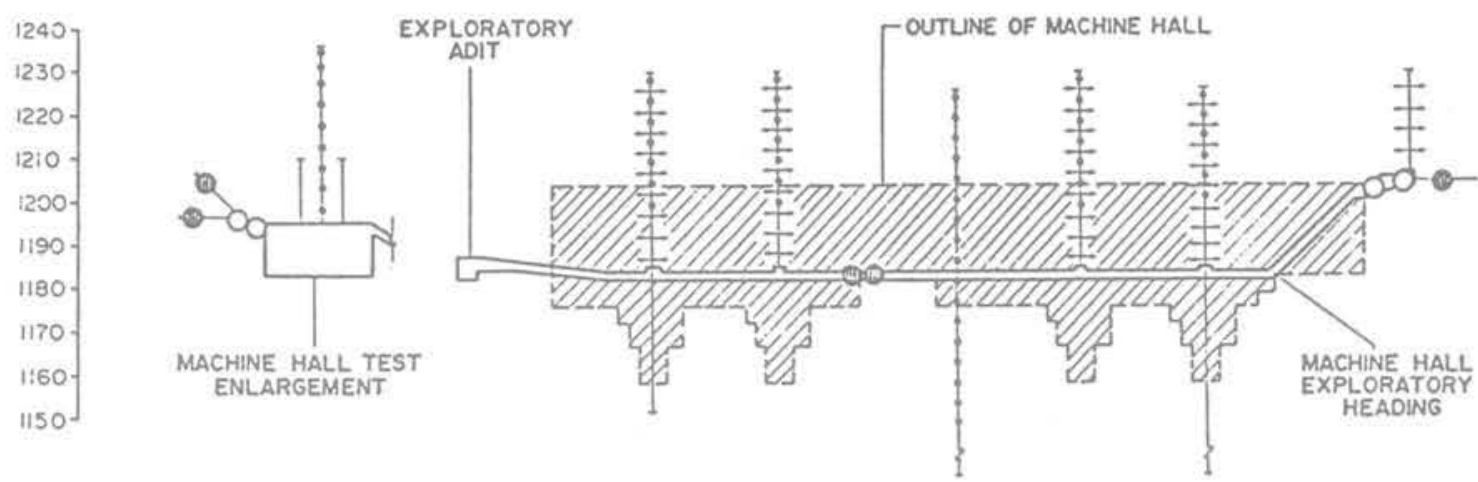

ELEVATIION $(\mathrm{m})$

ELEVATION

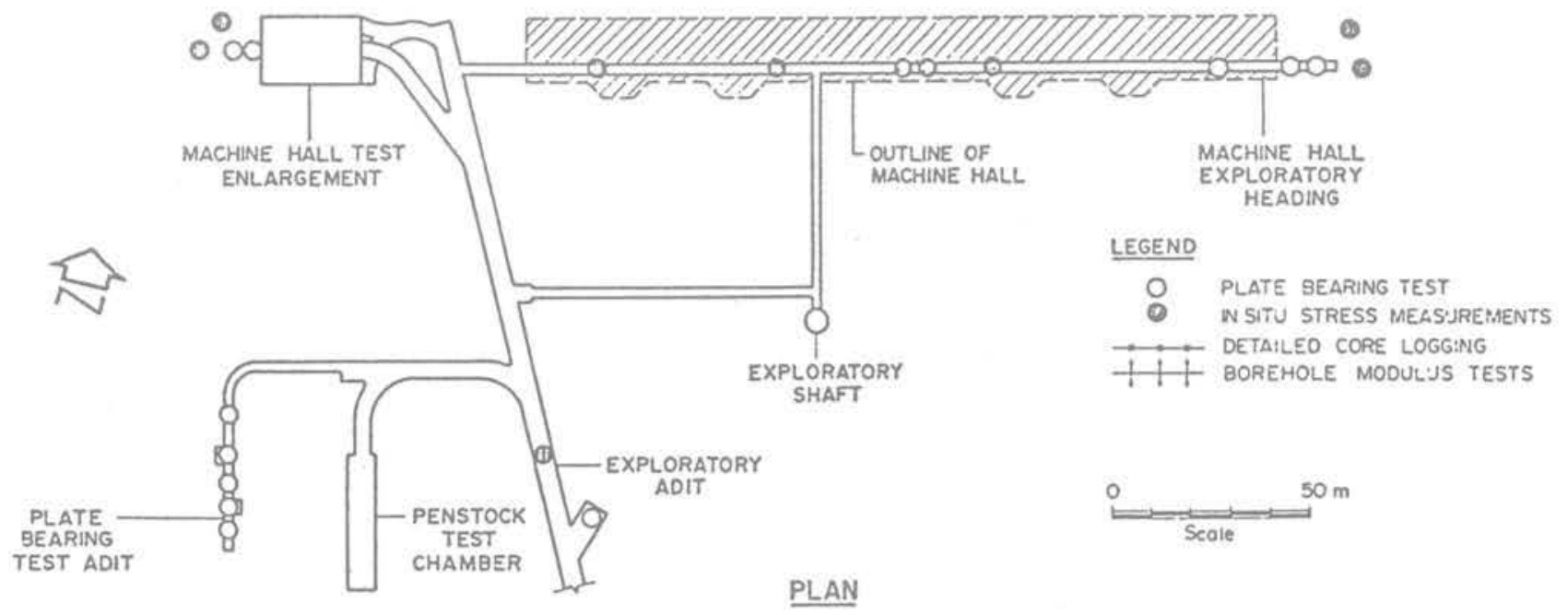

Fig. 2: Drakensberg pumped storage scheme - Layout of exploratory works and in situ test locations.

rock mass deformability. Only one paper contained some information on shear strength measurement which may be an indication of the difficulties of representative determination of this parameter in situ as well as a recognition of the advances made in the empirical determination of shear strength parameters (Barton 1977). No papers on thermal property determination were forthcoming.

\subsection{Rock mass deformability}

The most commonly accepted large scale deformability measurement technique is the plate loading test and loads up to 1000 tons on an area of the order of $1 \mathrm{~m}^{2}$ are now accepted practice. Between 1957 and 1982, some twentyfive programmes of rock mass deformability measurement using the plate loading test method have been carried out. Some of the published results are given in Table 3.

A second less popular method is the flat jack method that was developed largely by the late Dr. Rocha and his colleagues at LNEC in Portugal. Many sites have also been investigated using this method.

\section{Deformability Measurements: Dam Foundations}

Okamoto and his colleagues from Japn have reported on both plate bearing and flat jack tests carried out at four different dam sites located in various rock types, princi- pally granite, diorite and tuff. Valuable results are provided from their measurements. The flat jack type used is semicircular and has limited penetration into the rock mass. The effective loaded area is approximately $0,25 \mathrm{~m}^{2}$. In comparing plate bearing and flat jack tests, the latter are preferred by the authors as they believe that they are less affected by blasting damage. Details of the site preparation for the plate bearing tests are not given but clearly it is necessary to produce a representative surface by controlled blasting and if necessary manual excavation as they in fact did for their flat jack tests. Whilst they develop an expected correlation between deformation and elastic moduli, their correlations between modulus and rock type / weathering class show a significant degree of scatter indicating the influence of variability on the results particularly at the test scale selected.

Additional general information on dam foundation tests in Japan is given by Baba. The need for overall geological classification in relation to the selection of detailed test sites is emphasised but few test details or results are included.

Price Jones and Hobbs describe a series of 800 ton capacity plate load tests carried out in adits for the assessment of abutment conditions for the arch dam at the Victoria Project in Sri Lanka situated in high grade Precambrian metamorphic rocks. Useful practical details are given 
Tabl. 1: Example of in situ test programmes for underground cavern and pressure tunnel design (drakensberg pumped storage scheme)

Power station complex cavern design

Full scale observations in situ

Machine Hall Test Enlargement

- Displacement measurements (MPBX, Convergence, Levelling, Rock Bolts)

- Load measurements (Hydraulic support props, Rock bolt load cells)

- Stress change measurements (Embedded stress cells)

- Piezometric measurements (Hydraulic type piezometers)

- Rock determination observations (High resolution MPBX system direct observation)

In situ design property tests

Rock Mass Deformability

- Plate bearing tests (500 ton; horizontal and vertical on roof strata)

- Borehole modulus tests (Goodman jack tests [limited value])

- Geophysical measurements

Shear Strength

- Geometrical characterisation of significant planes of weakness (with laboratory testing)

In situ stress measurements

- Triaxial strain cell overcore tests from exploratory headings

High Head concrete lined pressure tunnel design

Full scale observations in situ

\section{Test Chamber}

- Displacement, stress and water pressure monitoring in rock

- Displacement, stress and strain measurements in lining

In situ design property tests

- Plate bearing tests ( 500 ton around test chamber periphery $\left[\mathrm{H}, \mathrm{V}, 45^{\circ} \mathrm{l}\right)$ Permeability testing at ambient and elevated pressures

\section{In situ stress measurements}

- Triaxial strain cell overcore tests from pilot tunnels

- Stress measurements in chamber lining

- Hydrofracture stress measurements from pilot tunnels

highlighting the need for careful test site preparation. The loading arrangement was conventional except that loads were measured in each loading column in addition to the loading plate flat jacks. No reasons are given as to the necessity of the extra load cells. Although the results were highly satisfactory from the dam designer's viewpoint giving in situ deformation moduli (close to elastic) in excess of $35 \mathrm{GPa}$, the small displacement, as measured by the extensometers, required particular care in their evaluation. In spite of a high resolution measurement system, displacements measured more than $2,5 \mathrm{~m}$ below the loading surface could not be interpreted.

In comparing the results from Victoria with those reported from Japan, a lesson on the need for thorough site prepa-

\section{Tab. 2: Distribution of papers: Topic 6}

Number of papers

$\begin{array}{cc}\text { Dam } & \text { Underground } \\ \text { foundations } & \text { works }\end{array}$

I. In situ design property tests

- Rock Mass Deformability

- Flat jack tests

- Plate bearing tests

- Radial jacking tests

- Pressure chamber tests

- Seismic methods

- Shear Strength

- Thermal Properties

IL. In situ stress measurements

- Flat jack me thod

1

- Borehole overcore methods

0

2

- Hydraulic fracturing and associated methods

III. Full scale observations in situ

- Underground Storage

- Tunnels

ration can be learned. It is however important to create a representative surface either of the rock mass or of the surface that may form the actual dam abutment when excavation methodology may require to be taken into account.

Fernandez Bollo and colleagues from Spain have reported on in situ flat jack tests using one or two (orthogonal) jacks typically $2 \mathrm{~m}^{2}$ in area. The paper provides a critical review of the measurement method and then gives outline details of time dependant tests for a damsite study.

\section{Deformability Measurements: Pressure Tunnels}

Within Topic 6, this class of measurements has received considerable attention with nearly all data being derived from chamber tests designed to act as a prototype for the actual structure. The use of large scale tests in this manner often coupled with seismic investigations to extend the test data to other geological conditions shows a promising trend in investigation methods. The use of such simulated tests recognises that the problem of rock support to pressure tunnel/penstock linings involves a complex interaction of geological, construction and stress variables that cannot necessarily be tested individually and the synthesised into a design model.

In the planning of chamber tests it is necessary to use an excavation technique that will be representative of the main tunnel excavation method and carry out tests in a representative geological and stress environment. Because of the complexity of the tests, it is normally only possible to carry out one or two tests at a given site and thus the results must be applied to the overall tunnel alignment by means of more general geological observations often employing geophysical methods.

Chamber tests that utilise water as their loading medium provide the best simulation of the pressure tunnel loading / 
Tab. 3/1: Selected plate bearing test data

TEST A P P A R A T U S

PLATE
DIMENSIONS
(CM)

TEST METHOD

IRAN

DAM
1957

Diorite

31

45

DEZ DAM

Conglo-

$257 \quad 25 \times 25$

TUMUT 2

AUSTRALIA

1960

Chert

OROVILLE POWER-

HOUS

CALIFORNIA 1961

ADIGUZEL DAM

TURKEY $1963 \begin{aligned} & \text { Marble, } \\ & \text { Schist }\end{aligned}$

HENDRIK VERWOERD

DAM

Dolerite

S. AFRICA 1965

P. X. LEROUX DAM

S. AFRICA 1965

ORANGE FISH

Mudstone

S. AFRICA 1965 Sandstone

ARCH DAM

$$
\text { Gneiss }
$$

CZECHOSLOVAKTA 1965

GRAN SUARNA DAM Quartzite

SPAIN

Quartite

HYDROELECTRIC DAM Limestone

USSR 1966

HYDROELECTRIC DAM

USSR 1966 Gneiss

HYDROELECTRIC DAM Bituminous

USSR

1966 Limestone

$\frac{\text { ROCK- }}{\text { PLATE }}$

LOADING

ORIENT-

$\frac{\text { DEFORMATION }}{\text { MEASUREMENTS }}$

Mortar

Hydraulic Inclined

Plate and

Rock Surface

Dial Gauges

Sulphur

Hydrauli

Jack

Plate Surface
Dial Gauges

\begin{tabular}{llll}
$\begin{array}{l}\text { Rubber } \\
\text { Concrete }\end{array}$ & $\begin{array}{l}\text { Hydraulic } \\
\text { Jack }\end{array}$ & - & $\begin{array}{l}\text { Plate and } \\
\text { Rock Surface } \\
\text { Dial Gauges }\end{array}$ \\
Concrete & $\begin{array}{l}\text { Hydraulic } \\
\text { Jack }\end{array}$ & $\begin{array}{l}\text { Horizontal } \\
\text { Vertical }\end{array}$ & $\begin{array}{l}\text { Center MPBX } \\
\text { TDG }\end{array}$ \\
\hline & &
\end{tabular}

Concrete Hydraulic Horizontal Jack

Rock Surface Dial Gauges

4 Inc.
Creep

Horizontal

Vertical

Horizontal

Vertical

Horizontal

Vertical

Hydraulic Horizontal Rock and

Plate Surface,

Plate Surface,
Dial Gauges

3 Inc.

Rock Surface

Dial Gauges

Neopren

Hydraulic

Horizontal

Vertical

Rock Surface

Dial Gauges

Rubber

Hydraulic Vertical

Jack

Rock Surface

Dial Gauges

Rock Surface

Dial Gauges

Rubber Hydraulic
Iortar Jack

Rubber Hydraulic Vertical Jack

6 Inc.

6 Inc.

\section{$\frac{\text { TESTING }}{\frac{\text { PRO- }}{\text { CEDURE }}} \frac{\text { TIME }}{\frac{\text { (DAYS) }}{\text { MAXIMUM }}} \frac{\frac{\text { MODULUS }}{\text { STRESS }}}{\frac{\text { (MPa) }}{\text { (MPa) }}}$ \\ CEDURE}

REFERENCE

(MPa)

$E_{S}=14.1$

Waldorf

Curtis 1963

4 Inc.

1.0

13.

$E_{S}=6.9 \quad$ Dodds,

to 12.4

$$
\begin{aligned}
& \mathrm{E}_{\mathrm{r}}=10.3 \\
& { }_{\mathrm{r}} 26.2
\end{aligned}
$$

\begin{tabular}{|c|c|c|}
\hline 10.9 & $\begin{array}{l}E=1.8 \\
\text { to } 51.7\end{array}$ & $\begin{array}{l}\text { Alexander, } \\
1960\end{array}$ \\
\hline - & $\begin{array}{l}E=8.3 \\
\text { to } 12.4\end{array}$ & $\begin{array}{l}\text { Kruse, } \\
1970\end{array}$ \\
\hline 6.9 & $\begin{array}{l}E_{u}=1.0 \\
\text { to } 12.3 \\
E_{t}=0.3 \\
\text { to } 3.3\end{array}$ & $\begin{array}{l}\text { Timur, } \\
1970\end{array}$ \\
\hline
\end{tabular}

(n)

E $=62.7$ Bieniauski, to $77.2 \quad 1978$

- $\quad E=18.6 \quad$ Bieniawski to $40.6 \quad 1978$

to 26.2

Bieniawski, 1978

8.0 $\quad E_{t}=1.8 \quad$ Drozd and

to 9.8 Louma,

$E_{r}=1.0 \quad 1966$
to 19.7

Serafim and Guerreiro, 1966

$=1,4$

to 53.5

Sapegin and

Shiryaev,

$E_{S}=.08 \quad$ Sapegic and Shiryaev,

1966

Sapegin and Shiryaev. 
Tab. 3/2: Selected plate bearing test data (continued)

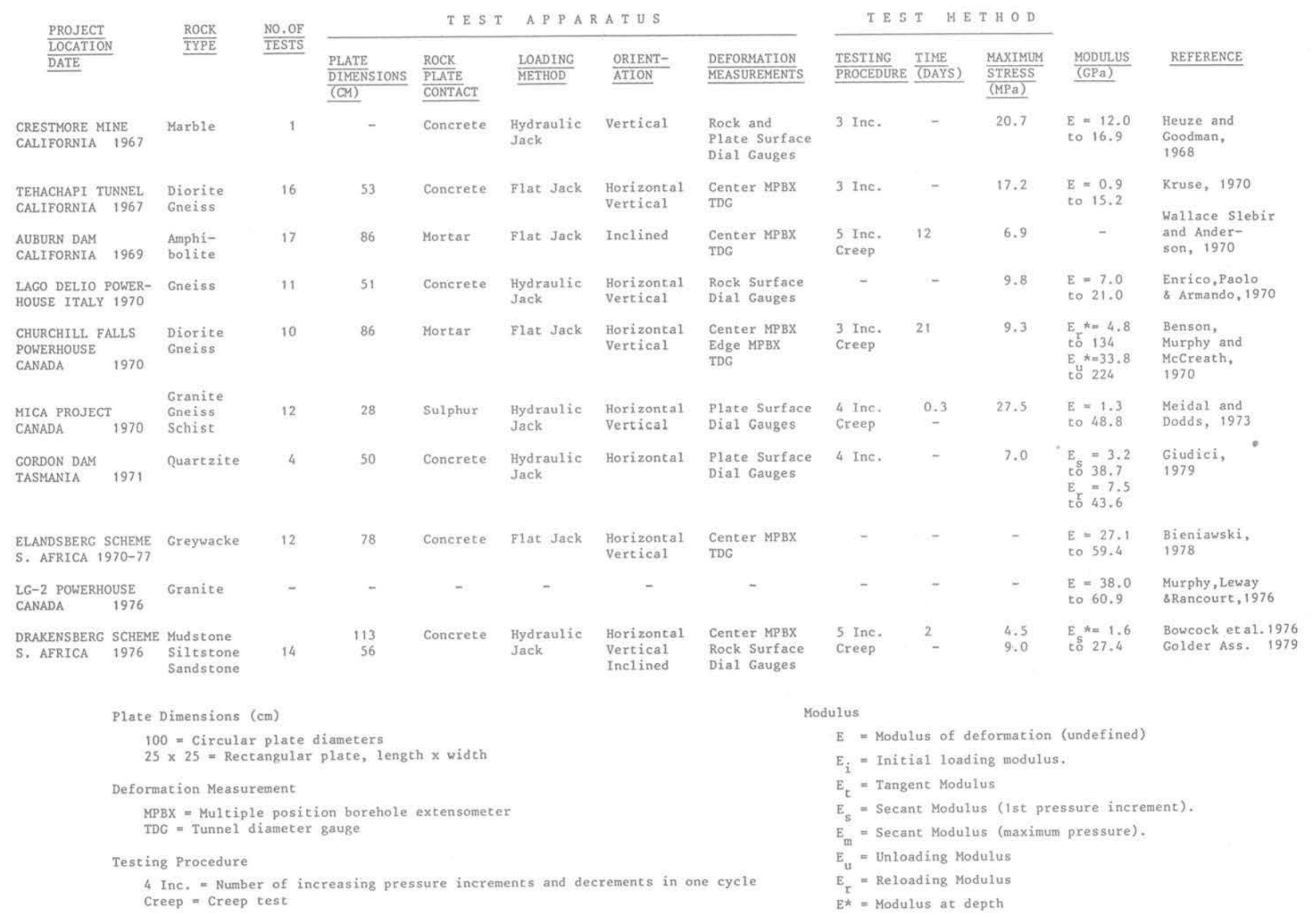


deformation state as they are able to take into account the effects of water pressure within the rock mass. This is particularly important for concrete-lined tunnels where leakage into the rock will inevitably occur unless special water-proof ing provisions are provided.

Other simulation tests such as the radial jacking test do not allow for the effect of water pressure in the rock mass and thus are better directed to the determination of the potential contribution of rock support to the dimensioning of steel linings. One major benefit of the radial jacking tests as opposed to chamber tests in the use of the test at mul. tiple locations along the completed tunnel alignment. This does however assume that testing and lining dimensioning can be carried out after tunnel excavation which may be at a late stage in the overall construction programme. The effect of grouting is obviously difficult to measure with this method.

A summary of past chamber test experience together with other modulus determination methods for pressure tunnel design is given in Table 3.

The use of the radial jack test in China is covered in a comprehensive paper on pressure tunnel investigations by Yang $\mathrm{Zi}$ Wen. Twenty-one tests on ten different projects are reported covering tunnel sections in granite, granodiorite, basalt, conglomerates, limestones and sedimentary rocks. The test techniques appear similar to those developed by TIWAG of Austria (Lauffer and Seeber 1961). In addition to providing a considerable amount of test data, studies covering the influence of cylinder length and the depth of influence of the jacking method are described. An interesting section of the paper deals with interpretation of rock mass anisotropy. For a tunnel section in altered basalt a ratio of maximum to minimum diametral deflections of 3.9 was recorded (vertical to horizontal). The anjsotropy is attributed to the rock mass but it is perhpas better explained by the potentially loosened zone above the crown giving exaggerated vertical deflections. Nevertheless such results are applicable to the resulting lining design unless the apparent deflection anisotropy can be reduced by grouting.

The use of chamber tests in conjunction with seismic methods to provide input to an analytical model simulating the various zones around a pressure tunnel are well illustrated by Doucerain from EDF, France. His paper describes tests conducted in granite at the Super Bissorte project to determine the participation of rock support in the steel liner design. The test chamber with a $2 \mathrm{~m}$ steel lining diameter had an excavated diameter of some $3,20 \mathrm{~m}$, a length of $30 \mathrm{~m}$ and was placed close to a fault zone some $300 \mathrm{~m}$ below surface. Extensometers were used to measure the response of tunnel loading into the rock which covered an internal pressure range up to $25 \mathrm{MPa}$ which is an extremely high loading in this type of test. The steel lining itself reached its elastic limit at about $10 \mathrm{MPa}$ internal pressure and was thus subjected to permanent deformations above this value. Seismic methods were used to define three distinct zones around the excavation corresponding to a disturbed zone, a transition zone and the undisturbed rock mass. The pressurisation tests together with the numerical model derived in conjunction with the radial deformability distribution taken from the seismic tests allowed the load taken by the steel and rock to be determined together with deformability values for the rock mass. Values of deformability between 50 and $100 \mathrm{GPa}$ were obtained after the first loading. Like other workers in this field the authors found that the values obtained from a confined chamber test were high in relation to values predicted from small scale test measurements. The overall test arrangement, measurement programmed and analytical interpretation have provided a good example of the use of in situ tests to provide representative design data for high head penstocks.

In situ tests at the Nurek Hydro Project (USSR) reported by Rukin and colleagues have been directed towards the use of 'polymercement' concrete linings developed to inhibit cracking where the stiffness of the rock surround permits excessive deformations. The use of latex additives in the concrete linings have reduced the overall concrete modulus two fold and allowed water tightness to be improved under enhanced deformation. A test tunnel comprising sections of ordinary and polymer concrete linings was constructed in the sandstone - silsttone rock mass. Limited contact grouting was undertaken. Using seismic measurements, it was established that a blast damaged zone up to $1,2 \mathrm{~m}$ thick was present compared with an excavation diameter of $3,1 \mathrm{~m}$ which appears to indicate limited control on the excavation method. Moduli of the surrounding rock mass were measured prior to and following grouting, the grouting resulting in a $50 \%$ increase in modulus to about $18 \mathrm{GPa}$. (This value appears very representative for the type of rock mass at the test site). Tests were conducted using both an internal loading frame (radial flat jack arrangement) and pressurisation of the entire chamber. Typical tests pressures were up to $1,4 \mathrm{MPa}$. Significant anisotropy in diametral deflections was observed with vertical deflections being some $2-3$ times horizontal. This again could be related to disturbance to the bedded strata in the tunnel crown as such values in the undisturbed rock mass do not seem plausible. The tests demonstrated the superiority of the polymer concrete linings over the ordinary concrete the latter exhibiting longitudinal cracks following pressurisation. Leakage rates were also comparatively less.

In relation to the internal pressures used, cracking in the ordinary concrete appears to have taken place at a relatively low pressure. This could have possibly been prevented or suppressed by more extensive grouting measures. The paper again is a good example of the use of representative test measurements to provide reliable data for tunnel lining design.

Another paper from the USSR by Lavrov describes the use of 'seismoacoustic' measurements along pressure tunnel alignments together with borehole ultrasonic methods to determine the effective deformability of the rock surround. He emphasises the important need to measure the deformation properties of the rock in the immediate vicinity of the excavation which has been disturbed by the excavation process and by stress redistribution. The methods discussed have been used on four major projects including the Inguri tunnel with a length of $15 \mathrm{~km}$ and a diameter of $9,5 \mathrm{~m}$. Some $25 \mathrm{~km}$ of seismic profiling and $6,4 \mathrm{~km}$ of borehole logging have been executed over the past 16 years. The use of radial boreholes allows detailed cross sections to be established which can then be extrapolated along the tunnel alignment by the longitudinal profiling. Useful descriptions are given concerning the results from a number of different rock types and using a three zone radial classification (near surface fractured zone / zone of relaxation/undisturbed rock) typical average values for depth and deformability are given. The theory used has been checked against static deformability tests (presumably plate bearing or chamber tests) and interesting data are provided on correlation factors. The method has also been extended to checking the adequacy of grouting behind the concrete lining of the Inguri tunnel using a total of 800 boreholes to depths of $8 \mathrm{~m}$. Although the techniques described are in use in a number of countries, the Russian work provides useful new 
data and may encourage other engineers to adopt or develop this approach.

Additional summary data from Japan has been provided by $\mathrm{Baba}$ and quotes results from the Shintoyone scheme where both steel lined and concrete lined chambers were constructed in granitic rocks.

\section{Deformability Measurements: Underground Excavations}

Unlike the case of pressure tunnels where one is trying to determine the 'reaction modulus' at the surface of a rock excavation, the design of large underground openings requires a knowledge of rock mass deformability.

The combined resources of ENEL and ISMES in Italy have over a number of years been studying a number of hydroelectric and pumped storage sites in various rock types in an attempt to develop general trends for underground excavation response. Their report to this conference concerns the interpretation of flat jack measurements in granitic metamorphic and sedimentary rocks. The flat jack arrangement used is the established method of drilling a series of overlapping holes. Like many researchers they have opted for relatively shallow jacks $(0,5 \mathrm{~m})$ in order presumably to overcome the problem of deflection measurements which they carry out using rigid rods anchored at the flat jack mid-plane. The measurements made (which were compared with other borehole stress data) allowed a comparison between the theoretical stress state at the jack location and that actually measured. A good agreement between theoretical (elastic) stresses and measured values was only obtained in the soft sedimentary rocks. In other cases the stress concentration was either less or greater than 2. For values less than 2, an attempt was made to obtain results on the residual strength parameters of the rock on the basis that yielding had occurred around the tunnel. As pointed out in the paper the results show that the flat jack measurements are not conclusive either in terms of the mechanical properties of the rock or the stress state. It would appear as others have found that the overlying assumption of elastic or at best a uniform but yielding rock is rarely applicable in rock masses particularly if disturbance due to the tunnel excavation has occurred. By correlating the flat jack data with other plate bearing test information and microseismic studies, a layer of loosened rock up to $0,8 \mathrm{~m}$ from the excavation surface was deduced. A further problem that arises is in the rotation of the measurement rods. This will be influenced in particular by unfavourably oriented rock structure and other inhomogeneities. The paper mentions that further study of the data will be carried out using a 3-D elastic, isotropic and homogeneous model. For the geometrical arrangement used (shallow jack emplacement) it is doubtful, given the uncertainties arising from geological and excavation conditions, whether meaningful values will ever be deduced. Furthermore the use of the data from flat jack tests in pressure tunnel design is considerably less direct thant the plate bearing or radial jacking test which loads in the same sense as the tunnel lining.

Additional laboratory studies have been conducted by Borsetto and colleagues from ISMES and ENEC in an attempt to further rationalise the in situ observations. The tests which were made on a $1 \mathrm{~m}$ concrete block show an expected agreement between measured and theoretical values. Problems of measurements of internal displacements are addressed and the rotation of rods (as used in their in situ experiments) was found to be quite significant. Their studies on a rather idealised 'massive' specimen tend to reinforce earlier doubts as to the applicability of shallow flat jack measurements for the determination of the mechanical properties of real rock masses.

\subsection{Rock mass shear strength}

The execution of shear tests for determining the strength of dam foundations is briefly reported by Baba from Japan. The test arrangement is fairly classical and no field results are quoted.

For both dam foundations and underground openings, the in situ measurement of joint shear strength remain a problem. With the standard ISRM test arrangement, the normal stiffness of the test specimen cannot be controlled and thus the major parameter controlling the strength of joints in in situ rock masses cannot be properly taken into account.

\section{In situ stress measurements}

The in situ state of stress has a well known influence on the stability and deformation properties of underground openings. Before dealing with actual measurements it is perhaps useful to mention that a great deal of information can be obtained from regional geological observations including the nature of deposition and erosion processes and tectonic events. In planning stress measurements it is thus useful to assess the likely stress field based on geological evidence.

A further general comment is concerned with the underlying assumptions of linear elasticity for the interpretation of many of the test methods. Whilst competent granitic rock masses may respond in this manner stresses are of ten not relevant in such rock types. In the weaker rocks where stress to strength ratios approaching unity may be encountered in common underground construction, the behaviour of the rock to an unloading stress path (common to all methods except hydrofracturing) may be quite non-linear. For such test methods it is very important to determine the relationship between stress and strain in the unloading mode on the same material sample as that used for the actual in situ measurements. (Gonano and Sharp 1983). Stress measurement programmes should not be embarked upon lightly. No measurements are better than the odd stress measurement. For many projects they may not be necessary and an estimation of stress ranges may be all that is required. Critical conditions in underground construction can be summarised as follows:

- excavation resulting in induced stress to strength ratios greater than 0,5

- geological environments where stresses may be highly anisotropic (near surface excavations in sedimentary rock)

- large shallow excavations in low stress environments - pressure tunnels in regions where the internal pressure is of the same order as the minimum principal stress.

The criteria governing the choice of method are complex and relate particularly to the nature of the rock. Because of uncertainties associated with all current methods, most well planned investigations will involve more than one method to provide a realistic degree of measurement redundancy and a cross check between results. In many rock masses significant variability in data should be expected and thus the test programme must be sufficiently comprehensive to cater for this. 
Tab. 4/1: Review of modulus determinations for various hydroelectric projects

DEZ DAM

DRAKENSBERC

good siltstones and greywacke, strong

schists, gneiss, phyllite

KAUNERTAL

KEMANO

LAGO DELIO

ORANGE FISH

ROCK CONDITIONS and cementation

impermeable inter-

similar to poor conglomerates of ariable composition

assessment of rock

support and over-

verify support capacity of grouted rock

and determine over-

design of pressure cunnel using pre stressed rock

$$
\text { support }
$$

rock modulus required for optimization of steel lining thickness

Instrumented steel sphere grouted into cavity

Plate Bearing Tests Pressure chambe Pack analysis of

\begin{tabular}{|c|c|c|}
\hline \multirow[t]{2}{*}{ Thests } & $\begin{array}{l}\text { mudstone } \\
\text { siltstone }\end{array}$ & $\begin{aligned} D_{s} & =8 \mathrm{GPa} \\
D^{5} & =35 \mathrm{GPa}\end{aligned}$ \\
\hline & sandst one & $\mathrm{D}^{\mathrm{s}}=25 \mathrm{GPa}$ \\
\hline \multirow[t]{3}{*}{ PBT } & mudstone & $\mathrm{D}_{\mathrm{s}}^{\mathrm{s}}=7 \mathrm{GPa}$ \\
\hline & siltstone & $D_{c}^{\mathrm{S}}=25 \mathrm{GPa}$ \\
\hline & sands stone & $25 \mathrm{GPa}$ \\
\hline \multicolumn{3}{|c|}{ Pressure Gallery } \\
\hline \multicolumn{2}{|c|}{$\begin{array}{l}\text { Tests (in silt/ } \\
\text { sandstone }\end{array}$} & $15-35$ \\
\hline
\end{tabular}

Laboratory Tests
Plate Bearing Tes $\mathrm{D}_{\mathrm{s}}^{\mathrm{s}}=8-10 \mathrm{GPa}$ $E^{s}=18-24 \mathrm{GP}$ depending on direction $D_{\mathrm{s}}=16-22 \mathrm{GPa}$ direction $D_{\mathrm{s}}^{\mathrm{d}}=21-53 \mathrm{CPa}$ bedding $\mathrm{D}_{\mathrm{s}}=19 \mathrm{GPa}$ perpendicular to

bedding

$D_{5}=15-30 \mathrm{GPa}$

$7-21 \mathrm{GPa}$ $10-27 \mathrm{GPa}$ 10-20 GPa
REMARKS

REFERENCE

Special attention to creep behaviour. Moduli are quoted secant values. Behaviour. of rock was very non-linear.

Plate Bearing Test results do not include disturbed zone. dêpending on

$E_{d}=46-58 \mathrm{GPa}$ parallel to Vertical modulus is signifi cantly less than horizontal.

Project Report Sharp \& Gonano (1982)

Substantial saving in steel effected by investigating rock support conditions under low cover

$D_{s}=6 \mathrm{GPa}$ bef- Design method using radial ore grouting jack testing and deformation $D_{s}=12 \mathrm{GPa}$ af- moduli is well established. ter grouting (for $15 \mathrm{GPa}$ used in design. At the time few designs relied on rock support to minimize steel thickness. Drakensberg
Lauffer \& Seeber (1962)

Brewer (1952)

Jaeger (1971)

Kidd et al. (1976)
On average, field values are about 0,6 times the laboratory values, pBr and pressure

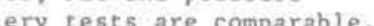


Tabl. 4/2: Review of modulus determinations for various hydroelectric projects (continued)

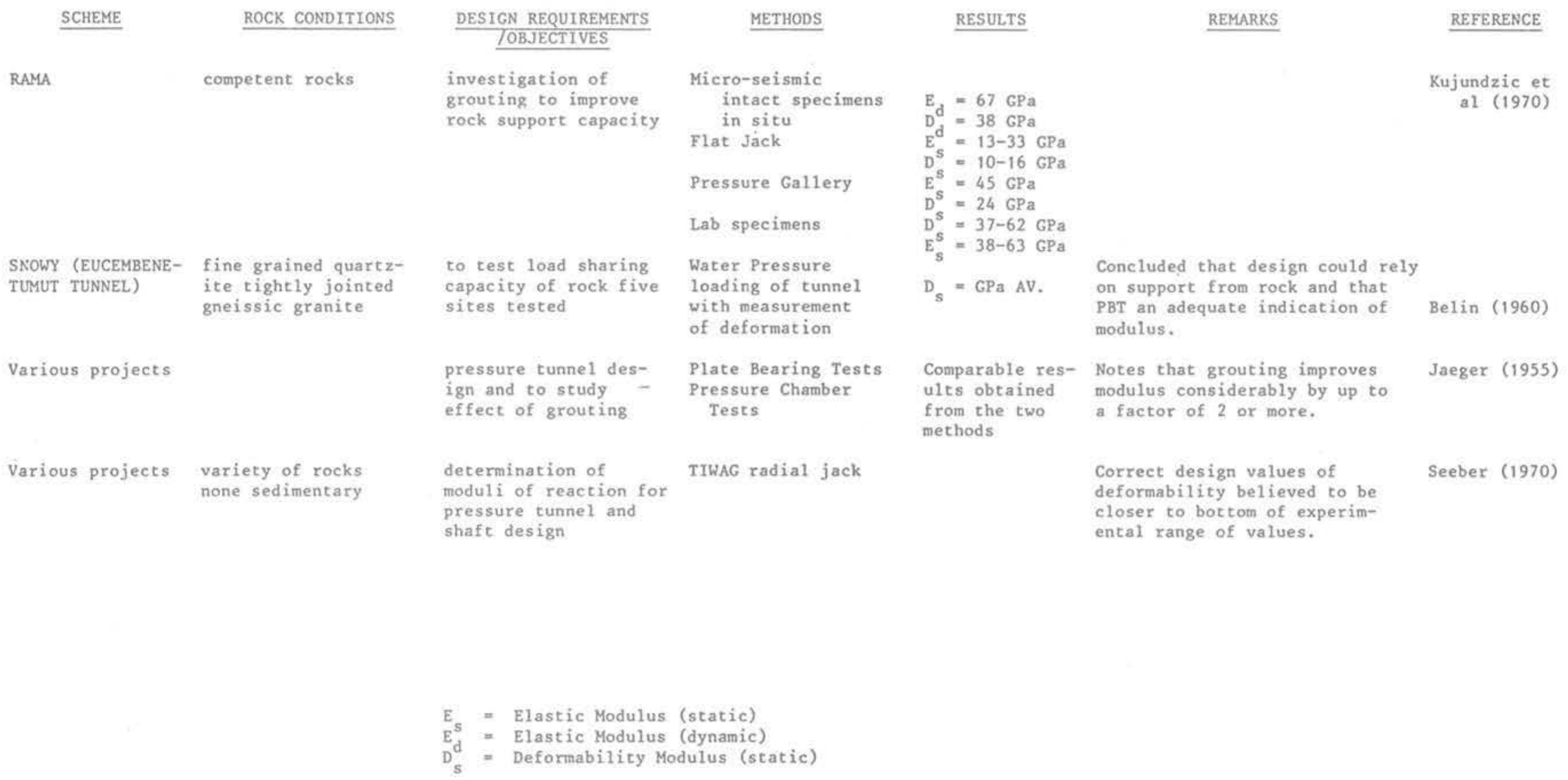




\subsection{Measurement methods}

Bertrand and Durand from BRGM in France have provided a survey of test methods dividing them into three main classes:

- flat jack relaxation method

- borehole overcore technique

- hydraulic fracturing.

In particular they point out the limitations of each method in the light of simplifying assymptions that are often required (linear eleasticity, undisturbed rock mass zone etc.). The main contributions of this paper are the results provided from the Sain Sylvestre granite massif. The geological history of the site has been carefully studied to provide geomorphological and tectonic evidence for regional stress orientations.

Tests were carried out broadly in the same area using all three methods. As usual interpretation of the flat jack measurements was influenced by assumptions regarding the stress concentrations around the adit periphery in which the tests were executed, the adit having been adversely influenced by blasting damage. More useful data were obtained from the borehole overcore tests which provided a basic indication of the governing stress field. Hydraulic fracturing tests were conducted both in a vertical borehole from surface and from horizontal boreholes underground. The data from the vertical hole gave a good correlation with the overcore test data for the minimum principal stress. These data in turn correlated well with the major tectonic activity associated with the alpine thrust. The authors have demonstrated the benefit of using overcoring tests together with hydraulic fracturing to provide a comprehensive understanding of stress conditions in relation to the geological environment. A similar test programme although at considerably greater depths was recently carried out in the granites in Cornwall, U.K. Again good correlation between overcoring, hydraulic fracturing and the major alpine thrust direction was obtained (Pine et al. 1983),

A contribution from Charrua - Graca from LNEC, Portugal describes a test programme involving both flat jack and overcoring measurements for a damsite foundation in an anisotropic schistose rock mass. The results of the flat jack programme were as usual adversely influenced by excavation disturbance and the validity of the gallery stress concentration model used was obviously questionable. Ten overcoring tests were made at three separate locations and biaxial tests were subsequently carried out on the overcore retrieved. The isotropic interpretation of the data was correctly viewed by the author as a limitation of the method. In spite of reservations about various aspects of the tests, a reasonable correlation was obtained between the two methods as shown by stereographic plotting of the principal stresses.

An interesting contribution on a new development using the sleeve fracturing technique has been provided by Stephansson from the University of Lulea, Sweden. The technique in principal is similar to the hydrofracture technique although problems regarding pore pressure assumptions and effective stress conditions are avoided by isolating the pressurising fluid from the rock. The use of the cell to determine other properties such as modulus suffers from the same limitations as the Goodman Jack and the CSM cell in that they can only be regarded as point measurements as far as most rock masses are concerned. Thus it cannot be considered as an adequate loading mechanism for the rock mass. In terms of stress measurement the method is a useful development but should it is suggested be used in conjunction with the hydrofracture technique. If used solely as a borehole technique, the principal advantage of hydrofracturing, namely the stressing of a representative volume of the rock mass is lost. (It is well know that all borehole methods require assumptions regarding the stress field around the borehole and that this can be modified by proximal fractures.) Although overcoming the uncertainty of pore fluid pressure conditions in the rock prior to fracturing, the method still requires assumptions on the tensile strength of the rock in order to obtain the maximum principal stress, a major difficulty that is inherent in the hydrofracture technique.

An exemple of the use of structural geological observations in predicting potential stress conditions followed up by extensive confirmatory measurements is given by Kazikaev from the USSR. The approach used is a good example of how stress measurements should be used to confirm the findings of prior geological evaluation. Too many stress measurement studies are carried out without prior thought for the geological environment and end up as a critique of the method rather than as an applied engineering study. The Russian data gives stress measurements over a depth range from 150 to nearly $400 \mathrm{~m}$ and interestingly show increasing ratios of horizontal to vertical stress with depth. Principal stress ellipses in relation to rock structure are presented showing how the stress conditions vary over the study region $\left(3 \mathrm{~km}^{2}\right)$. A further interesting finding relates to vertical stresses in a $100 \mathrm{~m}$ wide shale block bounded by quartzites. The vertical stresses in the shale corresponded to only $50 \%$ of those in the quartzites as a result of interactive support between the quartzites and the shale.

Most of the contributions reviewed so far have involved measurements in rocks where linear elasticity can be reasonably assumed and where time dependancy effects are small. Unfortunately not all engineering projects can be located in such easily understood materials and it is of ten necessary to understand stress conditions in weaker sedimentary rocks and salt deposits. (Particular attention is being focussed on salty rock formations for the disposal of radioactive waste products).

A contribution from Pahl and colleagues from Germany describes overcoring and flat jack tests in anhydrite and rock sait formations. They report initially on stresses within both intact and overloaded pillars and present interesting data on both absolute stress levels and horizontal to vertical stress ratios in anhydrite rock. Measurements in rock salt were also conducted using both methods. The rock stresses were calculated assuming linear elasticity, the effect of rock creep being compensated by using a dilatometer loading period equal to the overcore unloading period. The authors do not comment on the differences between the unloading and loading stress paths which could be significant in this type of rock.

Hydraulic fracturing stress measurements in a bedded salty deposit at a depth of some $700 \mathrm{~m}$ are described by Cornet and Thomas from France. Their paper presents a critical review of the hydrofracture method and the assumptions used. The use of properties derived from fracture propagation (second stage injection) to overcome assumptions regarding the tensile strength of the rock is proposed and examples are given of the results obtained from both methods. Results are provided from two sites in the same region. At the first site, three tests were carried out at a depth of some $700 \mathrm{~m}$ in a vertical borehole and attempts to obtain initial breakdown and repressurisation characteristics were made. At the second site two subhorizontal 
boreholes from galleries at a similar depth to the first site were tested. A good correspondence between the various tests was obtained indicating the validity of the method and assumptions used. In particular the results obtained from holes in different directions allow an improved understanding of the interrelationship of the principal stresses.

\section{Full scale in situ observations}

An important group of full scale tests has already been discussed for establishing design parameters for pressure tunnels. Other papers received have covered observations in salt cavities, low temperature caverns in argillites, measurements in coal mine roadways and settlement observations associated with road tunnels.

A paper from Hugout and Dussaud of France discusses the performance of gas storage in leached out salt cavities in which large pressure variations occur as a result of the operating conditions. Particular attention is focussed on volume losses amounting to some $30 \%$ over 10 years. A sonar survey after 10 years operation showed a significant heave of the floor of the cavity with little distress to the cavity roof. The changes in cavity volume are related to number of other factors besides creep such as thermal expansion, complementary dissolution and apparent compressibility. After devising tests with different liquid and gaseous fluids, it was found possible to isolate the creep component and produce reliable simulations of this factor using established creep laws and measured material properties.

The verification of creep behaviour on this overall scale and over a prolonged time period is a valuable development in the understanding of salt cavern behaviour.

Berest and colleagues from France have presented a new technique for determining the volume of underground storage caverns. By inducing a pressure drop at the well head and observing the subsequent pressure oscillations it is possible to relate the level response to the cavity volume knowing the compressibility characteristics of the fluid and the cavity walls. The theoretical studies which involve dynamic simulation of the overall system are applied to an actual cavern in salt filled with brine and fuel oil. Comparisons are made with a static compressibility method which is regarded as complementary to the dynamic method proposed. Data are given for a $7500 \mathrm{~m}^{3}$ cavern at various ambient pressures. The method proposed involves an elegant dynamic simulation approach and overcomes certain limitations of established static methods.

An interesting pilot study for a low temperature underground LNG storage cavern in clay is reported by $\mathrm{De}$ Sloovere from France. The need to study problems involving both high and low temperatures in underground excavation design is becoming increasingly common and it is fitting that at least one paper in this Topic should be concerned with thermal effects. The excavation has been created in a stiff eocene clay with a diameter of $3,7 \mathrm{~m}$ and a length of $100 \mathrm{~m}$ by means of a roadheader followed by a segmental concrete lining. The depth below surface is some $23 \mathrm{~m}$. A test section some $30 \mathrm{~m}$ long was cooled to $-196^{\circ} \mathrm{C}$ over the period November 1981 to June 1982. The temperature was maintained at that value until September 1982 and then allowed to recover. The response of the cavity to cooling was measured by multipoint extensometers on horizontal and vertical arrays and by fixed clinometers in vertical boreholes. In addition monitoring of the segmental concrete lining was undertaken together with monitoring of the excavated clay surface. Extensive use was made of vibrating wire instrumentation systems which were found to be the only reliable measurement method at the temperatures involved. In general the instrumentation appears to have behaved extremely well. The field results have been analysed by a study of displacement fields and induced stresses on the lining structure. Apart from being able to determine the interactive effects of the clay and chamber lining from the measured values, this type of pilot facility provides an extremely good overall demonstration of the feasibility of operating such underground structures under adverse thermal conditions. It is perhaps worth noting that similar studies to $+200^{\circ} \mathrm{C}$ are in the advance planning stages for the underground storage of nuclear waste materials.

A paper from China by Zhenxi and Guoliang provides interesting observed performance from underground openings in coal mines. Perhaps in the mining industry one has the greatest opportunity for developing designs through observed performance owing to the ongoing nature of the operation. Clearly in China where some $1000 \mathrm{~km}$ of shafts and tunnels per year are supported by bolting and shotcreting there is tremendous opportunity for optimisation. The instrumentation used is described and comprises convergence, extensometer and support load monitoring as well as acoustic investigation of the excavation srround. Results are given from the sites at depth in the range 270 $360 \mathrm{~m}$. As might be expected in coal measure rocks, closures of the order of $20 \mathrm{~mm}$ have been typically observed. The extent of rock loosening around the opening is of the order of $1,0 \mathrm{~m}$ for a $4 \mathrm{~m}$ wide roadway. The performance of the roadways subsequently subjected to coal seam extraction has also been monitored and additional closures of some $20 \mathrm{~mm}$ were measured when the face was within $\pm 50 \mathrm{~m}$ of the roadway location. From the evidence given it is apparent that the shotcrete lining in conjunction with bolting can in the softer rocks withstand up to $100 \mathrm{~mm}$ of closure without general distress. It is reported that some spalling of shotcrete in the crown has been observed (a rather typical occurrence in this type of rock) which requires remedial treatment. Use of mesh reinforcement in such areas generally improves the performance of the shotcrete lining. The paper reports a well planned and executed observations program which has allowed modern support techniques to be applied with confidence. In a world where we are still so often bound by tradition necessitating the continuing use of inefficient steel arch systems, this alternative, systematic approach is very encouraging.

The final paper on observed conditions concerns shallow tunnelling in Japan through sand and silt with an excavated cross section of some $85 \mathrm{~m}^{2}$. Yokoyama and colleagues have relied heavily on observations of tunnel performance together with borehole loading tests to estimate the magnitude of ground settlement and the stability of the tunnel face. Shotcrete, mesh and steel ribs together with anchor bars are used to stabilise the tunnel periphery. The ground characteristics in terms of stiffness are determined ahead of tunnelling using pressuremeter and borehole jacking tests. With the type of support used (relatively stiff) and the limited overburden depth, the main settlement problems are related to the behaviour of the tunnel face and the overlying ground ahead of the tunnel. Face collapse and caving are predicted from a study of ground settlements related to the material characteristics. The authors give a collapse criterion based on field measurements including studies of conditions before and after an actual failure of the face resulting in a ground settlement of some $40 \mathrm{~cm}$. The benefit of spiling bolts is also demonstrated in limiting ground settlements by up to $50 \%$. Such reports are always 
most valuable to the practising engineer particularly when they include observations of the actual failure state. Unfortunately without the occasional full scale failure to learn from it is extremely difficult to know the degree of conservatism in designs which are based solely on measurement of the material properties.

\section{Summary and conclusions}

The papers addressed to this Topic have covered a wide area. In particular valuable contributions have been made of full scale observations both under difficult ground conditions and for new types of engineering developments. The current status of the in situ test methods covered can be summarised as follows:

\section{In situ design property tests}

\section{Rock Mass Deformability}

The test must be related to the engineering product for which this data will be used. The deformability characteristics of both disturbed and undisturbed zones can be measured.

- Plate bearing tests are still the most useful current test. High loadings (up to 1000 tons) may be required in stiff rock masses to induce adequate deformations at depth for rock mass property determination. The tests can be extended over a wider site scale using geophysical methods.

- Flat jack testing is only meaningful in most fractured rock masses if a sufficient depth of jack emplacement can be achieved together with a measurement system within the rock mass. If internal jack deformation measurements are made (Rocha system) sawn slots are preferred. Shallow flat jack tests close to the rock surface using surface or borehole anchored systems do not yield representative data.

- For pressure tunnel design, full scale chamber tests together with geophysical classification along the tunnel alignment still provide the most reliable method for assessing long term support that may be derived from the rock. For concrete linings that may leak, water is the most effective loading medium as effective stress conditions in the rock can be observed directly.

\section{Shear Strength}

Large scale in situ shear tests are no longer considered justifiable except perhaps for major and unique planes of weakness affecting say the stability of a dam abutment. Problems remain in the execution of the test in relation to the correct representation of normal stiffness.

\section{In situ stress measurements}

The use of more than one test method to determine stress conditions is now common practice. Particularly valuable are combinations of the overcoring and hydrofracture methods. The overcore methods permit determination of the complete stress tensor although the absolute magnitude of the stresses measured is of ten influenced by rock property assumptions. They are also limited in relation to depth from access locations (surface or underground). The hydrofracture test is valuable in that it allows reliable determination of the minimum principal stress and can be conducted to great depth.

With the increasing use of deep bored shafts and tunnels, the overcored rosette method is also worthy of further consideration. (Brady et al., 1976).
The flat jack method as currently used in proximity to underground excavations is not recommended owing to the uncertainty and variability associated with stresses around underground openings.

\section{Full scale in situ observations}

The most valuable design basis is without doubt derived from full scale in situ performance observations. In tunnelling the approach is quite routine and used to determine support requirements as the project proceeds. For permanent underground caverns, trial or prototype openings have been constructed or are planned for many different uses including hydroelectric installations, gas and radioactive waste storage.

In spite of their apparently high cost, the potential design refinements that can be made and in particular the reduction in uncertainty during construction usually result in significant overall project savings. In many cases such trial openings may be essential to confirm the feasibility of a particular development.

\subsection{Future developments of in situ testing techniques}

From the papers presented it is encouraging to note that considerable emphasis is now being placed on the testing of soil and rock masses in situ at a scale that provides both a representative sample and a direct relationship to the engineering structure under consideration. Further testing developments should be aimed at providing representative mass information both for specific project sites and for rock masses in general.

Specific areas of development are suggested as follows:

\section{Rock mass deformability}

\section{Plate Bearing Test}

- Development of more sensitive displacement measurement systems together with increased load capacities for testing in stiff, undisturbed rock masses including long term creep evaluations.

- Determination of the state of stress under the loaded area as a function of the rock mass characteristics and the test excavation geometry.

- Development of improved correlation techniques between the plate bearing test and geophysical measurement methods.

\section{Flat Jack Test}

- Development of a deep slotting technique to allow emplacement of jacks within the undisturbed rock mass. Associated development of transverse MPBX system to measure deformations on a representative scale. Test layouts must incorporate facilities for drilling orthogonally to jacking plane. (Kim and Sharp, 1983).

- Development of improved correlation techniques between the flat jack test and geophysical measurement methods.

\section{In situ Block Tests}

- Loading of in situ rock samples in the form of blocks isolated in the walls or inverts of underground openings is becoming a relatively common form of test. Flat jacks emplaced around in slots are used for biaxial loading of the sample. Loading in the third direction can be carried out using stressing tendons which pass through the block itself. (Kim and Sharp 1983). 
- Further development of this test to determine rock mass deformability under a controlled state of stress (known boundary conditions) is advocated.

\section{Geophysical Measurements}

- Further development and increased usage of these measurements are proposed to provide a reliable means of sampling rock masses over a considerable extent.

\section{Shear strength}

- Continued development of empirical data and comparison with observed performance in situ.

- Development of a stiff in situ testing arrangement such as block shearing between parallel joint planes in a tunnel sidewall including measurements of stress and stiffness normal to the shear plane.

\section{In situ stress measurement}

- Extended use of test programmes incorporating measurements with more than one technique (combined overcore and hydrofracture tests).

- Development of existing techniques to overcome problems associated with rock mass structure.

- Development of the overcoring technique to permit its usage at depth in conjunction with hydrofracture measurements.

\section{Full scale in situ observations}

Continue emphasis on the value of such observations to develop a comprehensive understanding of rock mass response to the loading conditions imposed by the engineering structure. Particular attention should be focussed on the following areas:

- Non-watertight pressure tunnels with interaction between the water, lining and rock to evaluate long term support capacity and lining behaviour.

- Underground storage particularly at elevated pressures or where high thermal gradients are induced (gas, liquid and waste storage facilities).
- Tunnels in general to permit an improved understanding of rock behaviour and level of support requirements. - Large underground openings in weak ground requiring specific developments in support techniques.

\section{References}

BARTON N., and CHOUBEY V. (1977): Shear Strength of Rock Joints in Theory and Practice. Rock Mechanics 10, 1-54 (1977).

BRADY B.H.B., et al. (1976): Stress Measurement in a Bored Raise at the Mount Isa Mine. I.S.R.M. Symposium on Investigation of Stress in Rock, Advances in Stress Measurement, Sydney.

GONANO L.P. and SHARP J.C., (1983): Critical Evaluation of Rock Behaviour for In situ Stress Determination using Overcoring Methods. Proc. 5th Congress of Int. Soc. Rock Mech., Melbourne.

HARDIN E. et al., (1982): Measuring the Thermomechanical and Transport Properties of a Rockmass Using the Heated Block Test. Proc. 22nd U.S. Symposium on Rock Mechanics, Cambridge, Mass.

KIM K. and SHARP J.C., (1983): Design and Execution of a Large Scale Heated Block Test in Basalt to Determine the Thermomechanical Properties of Basalt under Triaxial Loading Conditions. Int. Symp. on Field Measurements in Geomechanics, Zurich, (to be presented).

LAUFFER H. and SEEBER G., (1961): Design and Control of Linings of Pressure Tunnels and Shafts, Based on Measurements of the Deformability of the Rock. Proc. 7th Congress of Large Dams, Rome, Report 91.

MELLORS T.W. and SHARP J.C., (1982): Investigations for the Drakensberg Power Stations Complex in Weak Sedimentary Rock. Proc. ISRM Symp. Rock Mech.: Caverns and Pressure Shafts, Aachen.

PINE R.J, et al, (1983): In situ Stress Measurement in the Cammenellis Granite; Part 1, Overcoring Tests at $790 \mathrm{~m}$; Part 2, Hydrofracture Tests to $2000 \mathrm{~m}$. Camborne Shool of Mines Geothermal Energy Project, I.J.R.M.M.S. (in press).

SHARP J.C. and GONANO L.P. (1982): Rock Engineering Aspects of the Concrete Lined Pressure Tunnels of the Drakensberg Pumped storage Scheme. Proc. ISRM Symp., Rock Mech.: Caverns and Pressure Shafts, Aachen. 